\title{
Prevention of Neomycin-induced Nephrotoxic Event in Pig Proximal Tubular Epithelial Cell Line by Apolipoprotein E3
}

\author{
Kozo Takamoto, Manabu Kawada, Daishiro Ikeda
}

Received: December 8, 2004 / Accepted: May 9, 2005

(C) Japan Antibiotics Research Association

\begin{abstract}
Nephrotoxicity is one of critical problems of aminoglycoside antibiotics. We examined the protective effect of apolipoprotein E3 (apoE3), one of ligands for megalin, on neomycin-induced extracellular release of lactate dehydrogenase, a marker of cell necrosis using pig proximal tubular LLC-PK 1 cells. Neomycin significantly induced the extracellular release of lactate dehydrogenase, but apoE3 successfully suppressed it. This result indicated that apoE3 protects the proximal tubular cells from the eventual cell death induced by nephrotoxic aminoglycosides.
\end{abstract}

Keywords nephrotoxicity, aminoglycosides, megalin, apolipoprotein E3, lactate dehydrogenase

Aminoglycosides are antibiotics worth using for the treatment of severe bacterial infections. Since aminoglycosides accumulate in renal proximal tubular cells, resulting in eventual cell death as a consequence of their nephrotoxicity, therapeutic monitoring is essential for the chemotherapy using aminoglycosides. Thus, the prevention of the nephrotoxicity of aminoglycosides has long been desired.

Recently, megalin has been implicated as a main route of renal aminoglycoside uptake [1,2]. Megalin is a large glycoprotein (about $600-\mathrm{kDa}$ ) that functions as a multiligand endocytic receptor related to the low-density

D. Ikeda (Corresponding author), K. Takamoto, M. Kawada: Numazu Bio-Medical Research Institute, Microbial Chemistry Research Center, 18-24 Miyamoto, Numazu-shi, Shizuoka 4100301, Japan, E-mail: numazu@bikaken.or.jp lipoprotein (LDL) receptor. Our previous study demonstrated that an apolipoprotein E3 (apoE3), one of ligands for megalin, significantly protects pig proximal tubular LLC-PK1 cells from gentamicin C (GMC)-induced reduction in SGLT1 $\left(\mathrm{Na}^{+} /\right.$glucose cotransporter) activity and from GMC-induced extracellular release of $N$-acethyl$\beta$-D-glucosamidase (NAG), a marker of lysosomal destabilization [3].

Neomycin is one of the most severe nephrotoxic aminoglycosides [4] and strongly inhibits the dome formation in $\mathrm{LLC}^{-\mathrm{PK}_{1}}$ cells [5]. The extracellular release of lactate dehydrogenase (LDH) is a marker of cell death and rupture of the cell membrane and significantly induced by severe nephrotoxic aminoglycosides such as neomycin and gentamicin $[6,7]$. In this study, using the model of extracellular release of LDH from LLC-PK 1 cells, we studied whether ligands for megalin protect the cells from neomycin-induced LDH release.

LLC-PK ${ }_{1}$ cells were obtained from ATCC (Manassas, VA) and maintained in a Dulbecco's modified Eagle's medium (DMEM; Nissui Pharmaceutical, Japan) supplemented with $10 \%$ fetal bovine serum (FBS) at $37^{\circ} \mathrm{C}$ in a $5 \% \mathrm{CO}_{2}$ environment without addition of antibiotics. We employed apoE3 (CALBIOCHEM) and lactoferrin (Sigma) as ligands for megalin. The cells were inoculated into a 96 -well plate at $2 \times 10^{5}$ cells $/ \mathrm{ml}(100 \mu \mathrm{l} /$ well $)$ with various concentrations of neomycin with or without $4.3 \mu \mathrm{g} / \mathrm{ml}$ of apoE3, $10 \mu \mathrm{g} / \mathrm{ml}$ of lactoferrin or $10 \mu \mathrm{g} / \mathrm{ml}$ of bovine serum albumin (Sigma), and incubated in DMEM supplemented with $5 \% \mathrm{FBS}$ at $37^{\circ} \mathrm{C}$ for 4 days. Thereafter, the supernatants of the cultured medium were retrieved and the extracellular release of LDH levels were measured immediately using a Cyto Tox 96 Non-Radioactive Cytotoxicity Assay (Promega) according to the manufacture's instructions. 


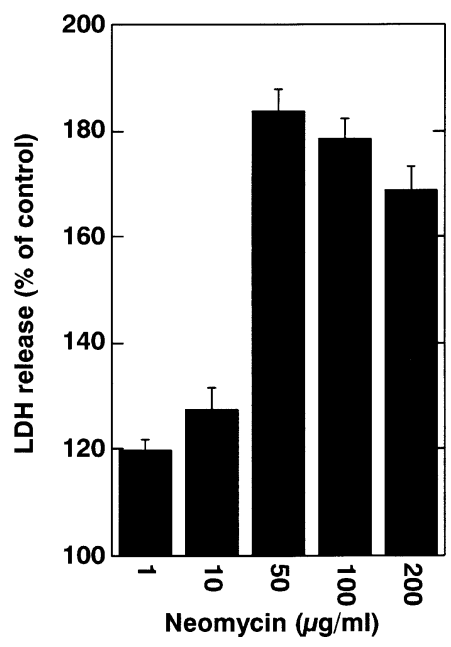

Fig. 1 Effect of various concentrations of neomycin on extracellular release of LDH in LLC-PK 1 cells.

To establish an appropriate model of neomycin-induced LDH release, the cells were cultured with the addition of $0 \sim 200 \mu \mathrm{g} / \mathrm{ml}$ of neomycin and the supernatants were immediately used for the measurement of the extracellular LDH levels. As shown in Fig. 1, neomycin induced the extracellular release of $\mathrm{LDH}$, with the peak release of $\mathrm{LDH}$ at the concentration of $50 \mu \mathrm{g} / \mathrm{ml}$ neomycin. Therefore, we used $50 \mu \mathrm{g} / \mathrm{ml}$ of neomycin for further experiments.

To confirm the protective effect of apoE3 or lactoferrin, considered to be ligands for megalin, the cells were inoculated with $4.3 \mu \mathrm{g} / \mathrm{ml}$ of apoE3, $10 \mu \mathrm{g} / \mathrm{ml}$ of lactoferrin and albumin with or without $50 \mu \mathrm{g} / \mathrm{ml}$ of neomycin. As shown in Fig. 2, the addition of $4.3 \mu \mathrm{g} / \mathrm{ml}$ of apoE3 significantly reduced the extracellular LDH level induced with $50 \mu \mathrm{g} / \mathrm{ml}$ of neomycin. In contrast to apoE3, neither lactoferrin nor albumin showed any improvement. These proteins stimulated extracellular LDH release in the presence of neomycin. Kounnas et al. reported that the lactoferrin presumably binds away from the binding site of apoE3 [8]. Though albumin constitutes the major plasma protein, megalin indirectly mediates endocytosis of albumin [9]. Therefore, it is suggested that the binding of lactoferrin or albumin to megalin does not affect the binding of aminoglycosides to the site of the receptor.

Taken together, this result indicates that apoE3 protects the cells not only from lysosomal destabilization as determined by NAG [3], but also from eventual cell death and rupture of the cell membrane as determined by LDH leakage in proximal tubular cells. In summary, apoE3 might have a protective effect against neomycin-induced LDH release in vitro via interference with a binding of aminoglycosides to the site of receptor.

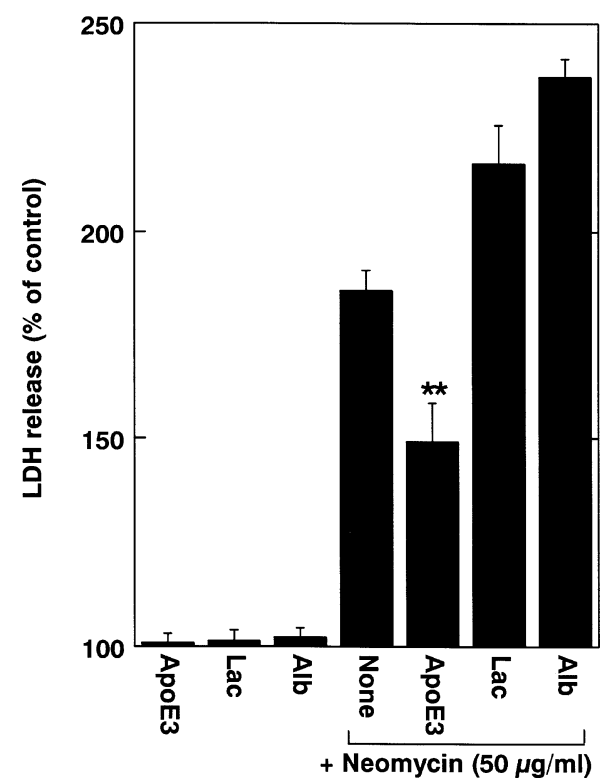

Fig. 2 Effect of ligands for megalin on neomycin-induced extracellular release of LDH in LLC-PK 1 cells.

${ }^{*} p<0.01$ vs. neomycin alone treated group. Lac, lactoferrin; Alb, albumin.

Acknowledgments This work was supported by a grant from the AstraZeneca Japan.

\section{References}

1. Schmitz C, Hilpert J, Jacobsen C, Boensch C, Christensen EI, Luft FC, Willnow TE. Megalin deficiency offers protection from renal aminoglycoside accumulation. J Biol Chem 277: 618-622 (2002)

2. Nagai J, Tanaka H, Nakanishi N, Murakami T, Takano M. Role of megalin in renal handling of aminoglycosides. Am J Physiol Renal Physiol 281: F337-F344 (2001)

3. Takamoto K, Kawada M, Ikeda D, Yoshida M. Apolipoprotein E3 (apoE3) safeguards pig proximal tubular LLC-PK 1 cells against reduction in SGLT1 activity induced by gentamicin C. Biochim Biophys Acta 1722: 247-253 (2005)

4. Kaloyanides GJ, Pastriza-Munoz E. Aminoglycoside nephrotoxicity. Kidney Int 18: 571-582 (1980)

5. Takamoto K, Kawada M, Usui T, Ikeda D, Ishizuka M, Takeuchi T. Inhibitory activity of dome formation in LLC$\mathrm{PK}_{1}$ cells is a selective index of aminoglycoside nephrotoxicity. J Antibiot 55: 605-606 (2002)

6. Girton RA, Sundin DP, Rosenberg ME. Clusterin protects renal tubular epithelial cells from gentamicin-mediated cytotoxicity. Am J Physiol Renal Physiol 282: F703-F709 (2002)

7. Blais A, Morvan-Baleynaud J, Friedlander G, Le Grimellec C. Primary culture of rabbit proximal tubules as a cellular model to study nephrotoxicity of xenobiotics. Kidney Int 44: 
13-18 (1993)

8. Kounnas MZ, Loukinova EB, Stefansson S, Harmony JAK, Brewer BH, Strickland DK, Argraves WS. Identification of glycoprotein 330 as an endocytic receptor for apolipoprotein J/clusterin. J Biol Chem 270: 13070-13075 (1995)
9. Birn H, Fyte JC, Jacobsen C, Mounier F, Verroust PJ, Ørskov H, Willnow TE, Moestrup SK, Christensen EI. Cubilin is an albumin binding protein important for renal tubular albumin reabsorption. J Clin Invest 105: 1353-1361 (2000) 